\title{
Article \\ Exploring the Stability of Fe-Ni Alloy Nanoparticles Exsolved from Double-Layered Perovskites for Dry Reforming of Methane
}

\author{
Alfonso J. Carrillo*(D) and José Manuel Serra * \\ Instituto de Tecnología Química, Universitat Politècnica de València-CSIC, Avda. Los Naranjos s/n, \\ 46022 Valencia, Spain \\ * Correspondence: alcardel@itq.upv.es (A.J.C.); jmserra@itq.upv.es (J.M.S.)
}

Citation: Carrillo, A.J.; Serra, J.M. Exploring the Stability of Fe-Ni Alloy Nanoparticles Exsolved from DoubleLayered Perovskites for Dry Reforming of Methane. Catalysts 2021, 11, 741. https://doi.org/10.3390/catal11060741

Academic Editor: Kalliopi Kousi

Received: 19 May 2021

Accepted: 15 June 2021

Published: 16 June 2021

Publisher's Note: MDPI stays neutral with regard to jurisdictional claims in published maps and institutional affiliations.

Copyright: (c) 2021 by the authors. Licensee MDPI, Basel, Switzerland. This article is an open access article distributed under the terms and conditions of the Creative Commons Attribution (CC BY) license (https:/ / creativecommons.org/licenses/by/ $4.0 /)$.
Abstract: Exsolution is emerging as a promising route for the creation of nanoparticles that remain anchored to the oxide support, imparting remarkable stability in high temperature chemical processes such as dry reforming of methane. This process takes place at temperatures around $850{ }^{\circ} \mathrm{C}$, which causes sintering-related issues in catalysts prepared using conventional impregnation methods, which could be overcome by using exsolution functionalized oxides. In this work, $\mathrm{FeNi}_{3}$ alloy nanoparticles exsolved from $\mathrm{Sr}_{2} \mathrm{Fe}_{x} \mathrm{Ni}_{1-\mathrm{x}} \mathrm{MoO}_{6-\delta}$ double-layered perovskites were evaluated as a dry reforming catalyst, paying special attention to structure-activity relationships. Our results indicate that increasing the $\mathrm{Ni}$ content favors the nanoparticle dispersion, eventually leading to increased $\mathrm{CO}_{2}$ and $\mathrm{CH}_{4}$ conversions. The exsolved nanoparticles presented remarkable nanoparticle size (ca. $30 \mathrm{~nm}$ ) stability after the $10 \mathrm{~h}$ treatment, although the formation of some phase segregations over the course of the reaction caused a minor decrease in the nanoparticle population. Overall, the results presented here serve as materials processing guidelines that could find further potential use in the design of more efficient (electro)catalysts in other fuel production or energy conversion technologies.

Keywords: exsolution; alloy nanoparticle; dry methane reforming; double-layer perovskite

\section{Introduction}

A myriad of chemical processes for the production of fuels, pharmaceuticals, fertilizers, or for environmental remediation rely on the use of a metal catalyst dispersed onto oxide supports [1]. These metallic nanoparticles represent the active sites in the heterogeneous reactions and are conventionally deposited on oxide supports (e.g., $\mathrm{Al}_{2} \mathrm{O}_{3}, \mathrm{ZrO}_{2}, \mathrm{CeO}_{2}$ ) using impregnation methods. However, in some chemical processes operating at high temperatures, metal nanoparticles created by impregnation can grow due to sintering related processes, resulting in an increase in the particle size and a decrease in the catalyst dispersion [2], which will eventually negatively affect their catalytic activity (Figure 1). This is, for example, the case of the dry reforming of methane (DMR) reaction (Equation (1)).

$$
\mathrm{CH}_{4}+\mathrm{CO}_{2} \rightarrow 2 \mathrm{CO}+2 \mathrm{H}_{2} \Delta \mathrm{H}_{r}=247 \mathrm{~kJ} \mathrm{~mol}^{-1}
$$

DMR is a promising technology for the conversion of $\mathrm{CH}_{4}$ and $\mathrm{CO}_{2}$ into syngas, which could be further transformed into liquid fuels through Fischer-Tropsch units. However, DMR faces two major issues related to (i) carbon depositions and (ii) metallic nanoparticle sintering, the latter being caused by the elevated process temperatures $\left(600-900{ }^{\circ} \mathrm{C}\right)$ [3].

In order to overcome these challenges, several alternatives have been pursued to obtain more stable metallic catalysts and supports. One method that has attracted attention in the past few years is nanoparticle exsolution due to the high stability that it confers to the metallic catalyst and the strong interaction with the support [2,4-6]. Exsolution consists of the creation of nanoparticles by the migration, under a reductive atmosphere, of cations contained in the bulk of the oxide support that nucleate and grow in the surface. Since the nanoparticles grow from inside, in contrast to the deposited particles, they remain anchored to the oxide surface, which provides high stability against sintering and 
coking (Figure 1) [7]. Most works have been focused on nanoparticle exsolution on perovskites [2,4,5], although lately, exsolution has also been observed on other oxides like in fluorite structures [8,9]. Perovskites, of the $\mathrm{ABO}_{3}$ formula (with $\mathrm{A}=\mathrm{La}, \mathrm{Sr}, \mathrm{Ca}, \mathrm{Ba}$, and $\mathrm{B}$, a transition metal cation) have been widely explored as catalysts for DMR based on their high thermal stability [10]. Therefore, it became apparent that exsolution-decorated metallic catalysts based on perovskites could find a remarkable niche of application in DMR $[10,11]$ or other high-temperature thermocatalytic processes such as the chemical looping reforming of methane [12-15]. To our knowledge, the first work devoted to DMR using nanoparticle exsolution was by Zubenko et al., who developed Re-Ni-Fe alloy nanoparticles exsolved from $\mathrm{LaNi}_{0.2} \mathrm{Re}_{0.2} \mathrm{Fe}_{0.6} \mathrm{O}_{3+\delta}-\mathrm{La}_{3} \mathrm{ReO}_{8}$ oxide with $\mathrm{x}<0.2$, with ca. $100 \% \mathrm{CH}_{4}$ and $\mathrm{CO}_{2}$ conversion at $900{ }^{\circ} \mathrm{C}$ [16]. One of the additional advantages of exsolution is the ability to create alloy nanoparticles in a facile manner by just adjusting the B-site composition in the perovskite host [16]. As illustrated by Zubenko et al., alloy exsolution can result in high catalytic activity. Other works that have explored bimetallic exsolution for DMR synthesized $\mathrm{Fe}-\mathrm{Ni}$, Co-Fe, and Co-Ni alloys exsolved from $\left(\mathrm{La}_{0.75} \mathrm{Sr}_{0.25}\right)\left(\mathrm{Cr}_{0.5} \mathrm{Fe}_{0.35} \mathrm{Ni}_{0.15}\right) \mathrm{O}_{3-\delta}$ [17], $\mathrm{Pr}_{0.5} \mathrm{Ba}_{0.5} \mathrm{Mn}_{0.85} \mathrm{Co}_{0.15} \mathrm{O}_{3-\delta}$ (infiltrated with Fe) [18], $\mathrm{Pr}_{0.5} \mathrm{Ba}_{0.5} \mathrm{Mn}_{0.85} \mathrm{Co}_{0.05} \mathrm{Ni}_{0.1} \mathrm{O}_{3-\delta}$ [19], and $\mathrm{La}\left(\mathrm{Co}_{0.1} \mathrm{Ni}_{0.9}\right)_{0.5} \mathrm{Fe}_{0.5} \mathrm{O}_{3}[20]$, respectively. The reported $\mathrm{CO}_{2}$ conversion values using exsolved alloys range from $81 \%$ for $\mathrm{Fe}-\mathrm{Ni}$ [17] to $30 \%$ for $\mathrm{Co}-\mathrm{Fe}$ [18], indicating a better DMR performance of the former. Interestingly, previous reports on bimetallic Fe-Ni catalysts over $\mathrm{La}_{2} \mathrm{O}_{3}$ showed that this catalyst has no activity to DMR due to encapsulation of $\mathrm{Ni}$ by a $\mathrm{LaFeO}_{3}$ phase [21]. Besides the work of Papargyriou et al., for DMR, several authors have explored Fe-Ni alloy exsolution, especially for solid oxide fuel cells and electrolyzers [22-25]. From these works, it can be noted that the double layer perovskite family $\mathrm{Sr}_{2} \mathrm{Fe}_{1-\mathrm{x}} \mathrm{Mo}_{\mathrm{x}} \mathrm{O}_{6}$ has been found to have excellent exsolution properties, in which $\mathrm{Ni}$ incorporation on the B-site allows for exsolving $\mathrm{Fe}-\mathrm{Ni}$ alloy nanoparticles after a reduction in $\mathrm{H}_{2}$. Despite the promise, these oxides have not been tested for DMR yet. For this reason, in this work, we performed a systematic analysis of the intrinsic (B-site composition) and extrinsic factors (time and temperature) to elucidate their effect on the nanoparticle size and dispersion, and, eventually, the structure-activity relationships in DMR.

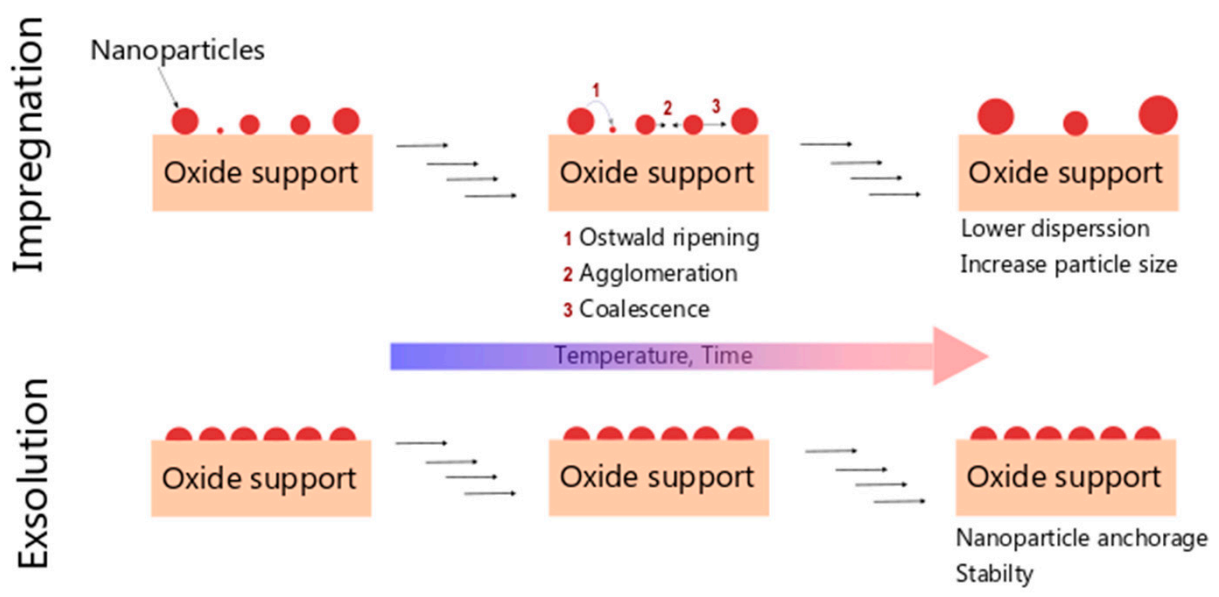

Figure 1. Schematic depicting the morphological evolution differences of dispersed metallic nanoparticles on oxide supports when prepared by impregnation or exsolution methods.

\section{Results}

2.1. Understanding $\mathrm{Fe}-\mathrm{Ni}$ Alloy Exsolution on $\mathrm{Sr}_{2} \mathrm{Fe}_{x} \mathrm{Ni}_{1-x} \mathrm{MoO}_{6-\delta}$

A series of four samples with $\mathrm{Sr}_{2} \mathrm{Fe}_{x} \mathrm{Ni}_{1-\mathrm{x}} \mathrm{MoO}_{6-\delta}$ composition $(\mathrm{x}=0.35-1$, see Table 1$)$ were synthesized via the Pechini method varying the Fe/Ni content. The X-ray patterns depicted in Figure 2a show that all the samples exhibited the tetragonal double-layer perovskite (ICSD 150701, space group, I4/m) as the main phase after the calcination treatment at $1100{ }^{\circ} \mathrm{C}$. However, the presence of a secondary impurity phase corresponding to $\mathrm{SrMoO}_{4}$ was observed for the four samples, in agreement with previous reports in 
the literature [26], caused by the high concentration of Mo above the solid solubility [27]. The presence of the impurity decreased with increasing amounts of Ni from $33.4 \mathrm{wt} \%$ for SFMO to $9.3 \mathrm{wt} \%$ for SFNM35, as analyzed by Rietveld refinement (see example in Figure S1). The increasing presence of Ni stabilized the double-layered perovskite due to its lower oxidation state $(+2)$, which facilitated the presence of Mo in +6 while maintaining charge neutrality. In order to drive the exsolution of metallic nanoparticles, the as-synthesized perovskite powders were treated with a $5 \% \mathrm{H}_{2}$ atmosphere at $900{ }^{\circ} \mathrm{C}$ for $2 \mathrm{~h}$. Figure $2 \mathrm{~b}$ depicts the $\mathrm{XRD}$ patterns of the four samples after such treatment. It can be seen that the amount of $\mathrm{SrMoO}_{4}$ impurities decreased after the treatment in $\mathrm{H}_{2}$, whereas for SFNM50 and SFNM35, the appearance of minor impurities of a Ruddlesden-Popper-like phase $\mathrm{Sr}_{3} \mathrm{MoO}_{7}$ was observed. Nevertheless, the double-layered perovskite phase purity increased for the four samples upon hydrogen treatment (Table 1). For instance, SFNM65 purity increased from 83.5 to $86.7 \%$. Importantly, after the $2 \mathrm{~h}$ treatment, a negligible phase transition from the double layer perovskite structure to a Ruddlesden-Popper could be ascertained, which was observed previously with other similar compositions (e.g., $\mathrm{Sr}_{2} \mathrm{Fe}_{1.35} \mathrm{Mo}_{0.45} \mathrm{Co}_{0.2} \mathrm{O}_{6-\delta}$ ) [28]. The differences between both works might arise from the different concentration of $\mathrm{Fe}$ and Mo on the B-site. In order to provide more insights on the crystallographic changes that occur upon exsolution, we conducted an in situ XRD analysis by heating the SFNM50 sample up to $800{ }^{\circ} \mathrm{C}$ under a $5 \% \mathrm{H}_{2}$ atmosphere. Figure $2 \mathrm{c}$ shows the evolution of the (1 112 ) reflection located at ca. $32^{\circ}$ (room temperature). Upon heating in the $\mathrm{H}_{2}$ reductive atmosphere, the main reflection gradually shifted toward lower $2 \theta$ values. This behavior can be ascribed to the lattice expansion originated by the formation of oxygen vacancies upon reduction and confirms the rise in cell volume as determined from the ex-situ XRD analyses (Table 1). Unfortunately, we were not able to detect the appearance of metal nanoparticles with the current setup, although, as it will be discussed later, these conditions led to metallic nanoparticle exsolution (Figure 3). Figure $2 \mathrm{~d}$ collects the temperature evolution of the cell volume and lattice parameters as determined by Rietveld refinement. Cell volume for SFNM50 increased from ca. $244 \AA^{3}$ at $100{ }^{\circ} \mathrm{C}$ to ca. $251 \AA^{3}$ at $800{ }^{\circ} \mathrm{C}$. Both $a$ - and $c$-axes from the tetragonal double-layer perovskite lattice elongated upon heating up in the $\mathrm{H}_{2}$ atmosphere.

Now we turn to the morphological analyses of the materials after the exsolution treatment. Figure 3 depicts the SEM images of the four $\mathrm{Sr}_{2} \mathrm{Fe}_{x} \mathrm{Ni}_{1-\mathrm{x}} \mathrm{MoO}_{6-\delta}$ samples after $2 \mathrm{~h}$ exposure to a $5 \% \mathrm{H}_{2}$ atmosphere at $900{ }^{\circ} \mathrm{C}$. As observed in the SEM images, all the samples exhibited the presence of well-dispersed nanoparticles covering the surface of the porous perovskite except for the sample without $\mathrm{Ni}$, SFMO. Based on this fact, it seems that the presence of $\mathrm{Ni}$ on the B-site boosts the metallic nanoparticle exsolution. In the literature, there is a certain discrepancy about the possible exsolution of Fe from SFMO materials. On one hand, $\mathrm{Lv}$ and coauthors stated that $\mathrm{Sr}_{2} \mathrm{Fe}_{1.5} \mathrm{MoO}_{6-\delta}$ was stable under reductive environments at high temperatures without evidence of metallic Fe nanoparticle exsolution [28]. They obtained the segregation energy of Fe through DFT calculations, which was $0.91 \mathrm{eV}$, whereas that of Co was $-0.64 \mathrm{eV}$. These results show that Co exsolution is more thermodynamically favored with respect to Fe in SFMO-like double-layered perovskites. On the other hand, Chen et al. obtained a metallic Fe exsolution from $\mathrm{Sr}_{2} \mathrm{Fe}_{1.5+\mathrm{x}} \mathrm{Mo}_{0.5} \mathrm{O}_{6-\delta}$ $(x=0-0.1)$ [29]. In that work, the authors increased the concentration of Fe on the B-site to promote the exsolution of Fe nanoparticles of about $95 \mathrm{~nm}$ after $3 \mathrm{~h}$ exsolution at $850{ }^{\circ} \mathrm{C}$. Thus, it seems that without Fe excess, as was the case of the present work, Fe exsolution will unlikely happen due to thermodynamic unfavorability, which can be altered by compositional modifications. In the case of the three samples with the presence of $\mathrm{Ni}$ on the B-site, nanoparticle exsolution was observed on the surface of the oxide. The nanoparticles were well dispersed over the double-layered perovskite, without evidence of preferential location for the exsolution. Regarding the size, most of the nanoparticles presented diameters in the $20-50 \mathrm{~nm}$ range. A more thorough analysis of the nanoparticle size and distribution, and its dependence with exsolution conditions will be covered in the following sections. 
Table 1. Label, formula, and crystallographic data of the four $\mathrm{Sr}_{2} \mathrm{Fe}_{x} \mathrm{Ni}_{1-\mathrm{x}} \mathrm{MoO}_{6-\delta}$ samples before and after exsolution.

\begin{tabular}{|c|c|c|c|c|c|c|c|}
\hline \multirow{2}{*}{ Label } & \multirow{2}{*}{ Formula } & \multicolumn{3}{|c|}{ As Prepared } & \multicolumn{3}{|c|}{ After Exsolution $2 \mathrm{~h}, 900^{\circ} \mathrm{C}, 5 \% \mathrm{H}_{2}$} \\
\hline & & $\begin{array}{l}\text { Crystal Phase } \\
\text { (Space Group) }\end{array}$ & $\begin{array}{c}\text { Cell Vol. } \\
\left(\AA^{3}\right)\end{array}$ & $\begin{array}{c}\text { Phase } \\
\text { Purity \% }\end{array}$ & $\begin{array}{l}\text { Crystal Phase } \\
\text { (Space Group) }\end{array}$ & $\begin{array}{c}\text { Cell Vol. } \\
\left(\AA^{3}\right)\end{array}$ & $\begin{array}{c}\text { Phase } \\
\text { Purity \% }\end{array}$ \\
\hline SFMO & $\mathrm{Sr}_{2} \mathrm{FeMoO}_{6-\delta}$ & $\begin{array}{l}\text { Tetragonal } \\
(\mathrm{I} 4 / \mathrm{m})\end{array}$ & 244.2 & 66.6 & $\begin{array}{l}\text { Tetragonal } \\
(\mathrm{I} 4 / \mathrm{m})\end{array}$ & 244.9 & 69.1 \\
\hline SFNM65 & $\mathrm{Sr}_{2} \mathrm{Fe}_{0.65} \mathrm{Ni}_{0.35} \mathrm{MoO}_{6-\delta}$ & $\begin{array}{l}\text { Tetragonal } \\
(\mathrm{I} 4 / \mathrm{m})\end{array}$ & 244.4 & 83.5 & $\begin{array}{l}\text { Tetragonal } \\
(\mathrm{I} 4 / \mathrm{m})\end{array}$ & 244.6 & 86.7 \\
\hline SFNM50 & $\mathrm{Sr}_{2} \mathrm{Fe}_{0.5} \mathrm{Ni}_{0.5} \mathrm{MoO}_{6-\delta}$ & $\begin{array}{l}\text { Tetragonal } \\
(\mathrm{I} 4 / \mathrm{m})\end{array}$ & 243.9 & 86.6 & $\begin{array}{l}\text { Tetragonal } \\
(\mathrm{I} 4 / \mathrm{m})\end{array}$ & 244.4 & 90.6 \\
\hline SFNM35 & $\mathrm{Sr}_{2} \mathrm{Fe}_{0.35} \mathrm{Ni}_{0.65} \mathrm{MoO}_{6-\delta}$ & $\begin{array}{l}\text { Tetragonal } \\
(\mathrm{I} 4 / \mathrm{m})\end{array}$ & 243.8 & 90.7 & $\begin{array}{l}\text { Tetragonal } \\
(\mathrm{I} 4 / \mathrm{m})\end{array}$ & 244.5 & 92.2 \\
\hline
\end{tabular}

a
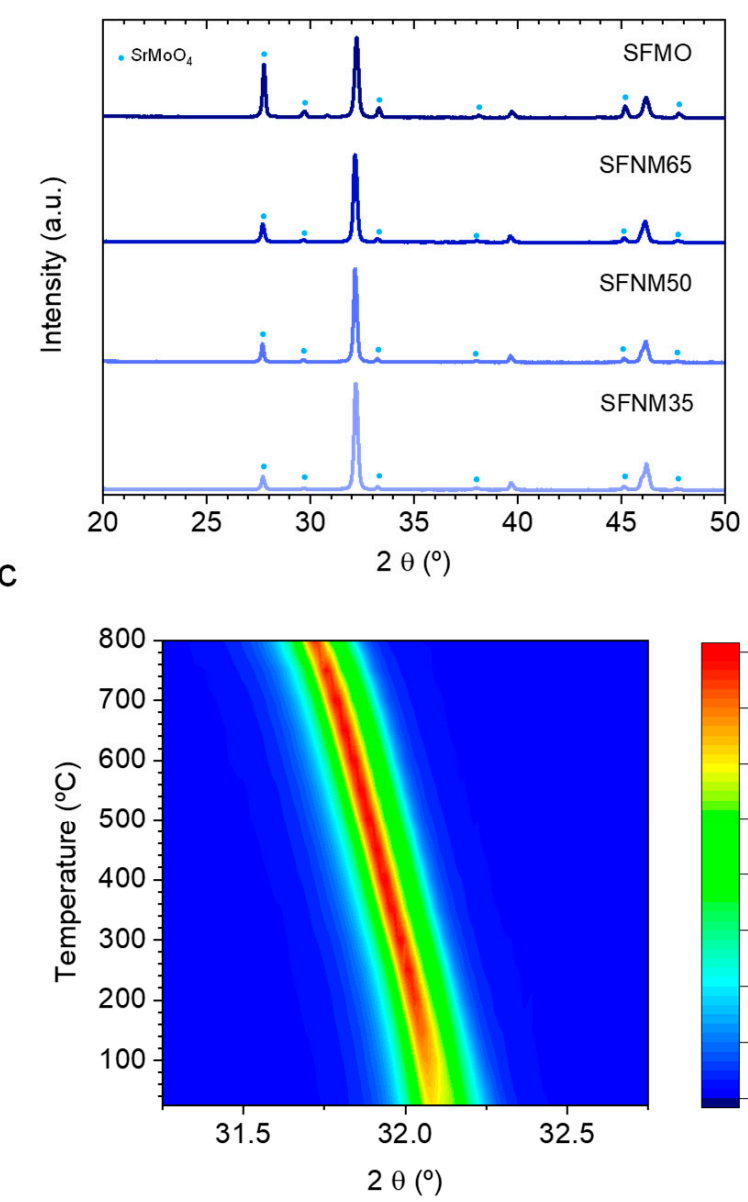

b
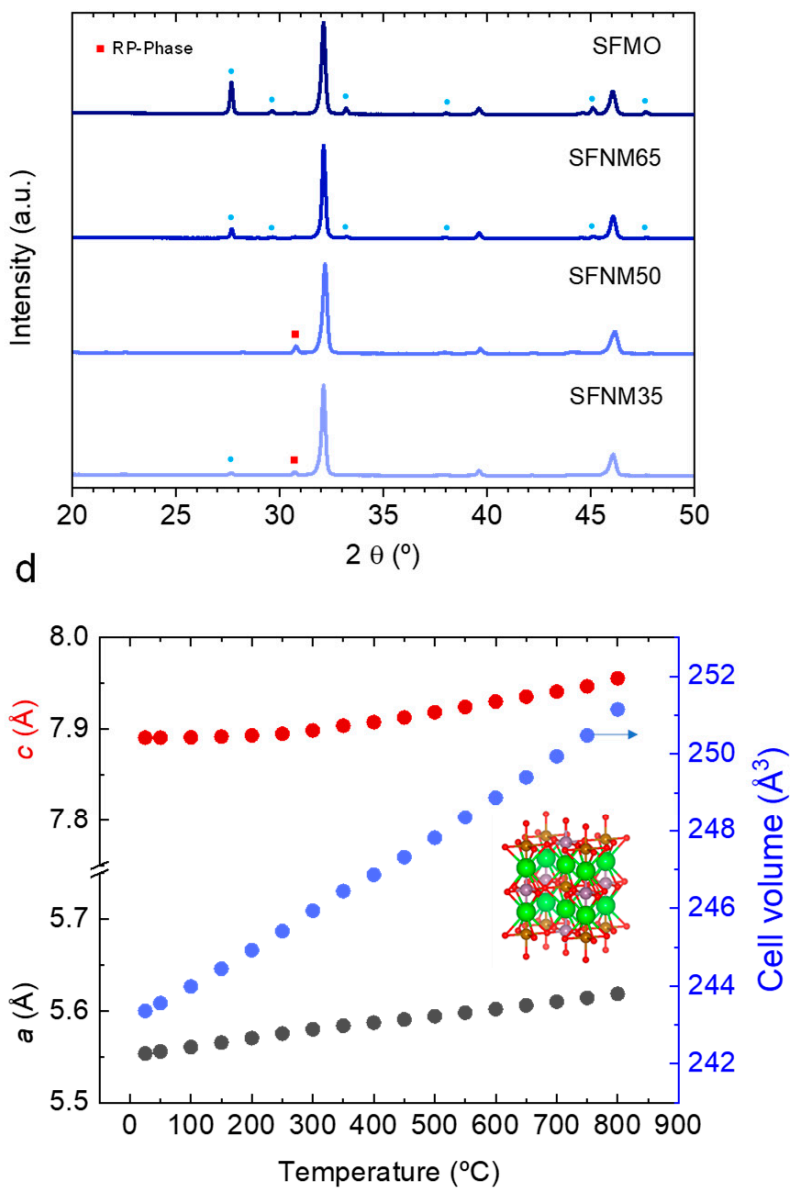

Figure 2. (a) XRD diffractograms of the $\mathrm{Sr}_{2} \mathrm{Fe}_{\mathrm{X}} \mathrm{Ni}_{1-\mathrm{x}} \mathrm{MoO}_{6-\delta}$ materials as-synthesized (calcination at $1100{ }^{\circ} \mathrm{C}$ in air). (b) XRD diffractograms of the $\mathrm{Sr}_{2} \mathrm{Fe}_{x} \mathrm{Ni}_{1-x} \mathrm{MoO}_{6-\delta}$ materials after the exsolution treatment $\left(5 \% \mathrm{H}_{2}, 900{ }^{\circ} \mathrm{C}, 2 \mathrm{~h}\right)$. (c) In situ XRD experiment performed to SFNM50, heating up to $800{ }^{\circ} \mathrm{C}$ under $5 \% \mathrm{H}_{2}$. The selected zone depicts the most intense reflection of the tetragonal double layer perovskite. (d) Tetragonal lattice parameters (a,c) and lattice volume variation extracted from the in situ XRD tests for the SFNM50 sample. The schematic inside the figure depicts the tetragonal double layer perovskite crystalline structure (green, red, purple, and brown spheres are $\mathrm{Sr}, \mathrm{O}, \mathrm{Mo}$, and Fe/Ni atoms, respectively).

Next, we analyzed SFNM65 samples with TEM in order to better understand the nature of the exsolved nanoparticles. Figure 4a shows the HRTEM images of the SFNM65 sample after $2 \mathrm{~h}$ exsolution under $5 \% \mathrm{H}_{2}$ at $900{ }^{\circ} \mathrm{C}$. The presence of exsolved nanoparticles of about $20 \mathrm{~nm}$ size were observed, which were partly submerged into the perovskite backbone. This characteristic anchoring, typical of nanoparticle exsolution, avoids sintering 
with neighboring particles due to the high degree of attachment of the nanoparticles to the oxide surface. Figure $4 \mathrm{~b}-\mathrm{f}$ shows the HAADF-STEM image and EDX mapping of the five elements that compose the double-layer perovskite. These images provide important insights on the composition of the exsolved nanoparticles. As can be seen in the EDX mapping in Figure 4c,d, the nanoparticles were composed of both $\mathrm{Ni}$ and $\mathrm{Fe}$, thus the reductive treatment performed in this work resulted in the exsolution of the $\mathrm{Ni}-\mathrm{Fe}$ alloy nanoparticles from $\mathrm{Sr}_{2} \mathrm{Fe}_{x} \mathrm{Ni}_{1-\mathrm{x}} \mathrm{MoO}_{6-\delta}$ materials while maintaining the double-layer perovskite structure. As observed in Figure $4 \mathrm{c}-\mathrm{g}$, the presence of the initial five elements that composed the perovskite was detected in the backbone, whereas only $\mathrm{Fe}$ and $\mathrm{Ni}$ were observed in the exsolved nanoparticles. $\mathrm{Fe}-\mathrm{Ni}$ alloy exsolution has been previously reported in Sr-Fe-Mo based perovskites [22,30-32], titanates [25], and chromites [17,33]. In most of these cases, the composition of the exsolved alloy was $\mathrm{FeNi}_{3}$. For instance, in the work of Du et al., they obtained $\mathrm{FeNi}_{3}$ exsolution from $\mathrm{Sr}_{2} \mathrm{FeMo}_{0.65} \mathrm{Ni}_{0.35} \mathrm{O}_{6-\delta}$ after $10 \mathrm{~h}$ of treatment in pure $\mathrm{H}_{2}$ [22]. Increased exposure times and higher $\mathrm{H}_{2}$ concentrations, as performed by Du et al. compared to our work, commonly resulted in larger particle sizes $[34,35]$. Formation of larger particles could eventually ease their detection by XRD, and, thus the identification of the actual alloy composition of the exsolved nanoparticles. For that reason, we performed a $20 \mathrm{~h}$ exsolution treatment at $900{ }^{\circ} \mathrm{C}$ in a $5 \% \mathrm{H}_{2}$ atmosphere. Figure 5a depicts a comparison of the XRD patterns for SFNM65 as-synthesized, and after 2 and $20 \mathrm{~h}$ exsolution. The exsolution time increase lead to several changes in the crystal structure of the SFNM65 material. First, the impurities of $\mathrm{SrMoO}_{4}$ disappeared. Second, there was a remarkable phase transformation, resulting in the formation of a Ruddlesden-Popper phase $\mathrm{Sr}_{3} \mathrm{FeMoO}_{7}$ (ICSD 152243). This result is in line with previous reports by $\mathrm{Du}$ et al. ( $\mathrm{FeNi}_{3}$ exsolution from $\mathrm{Sr}_{2} \mathrm{FeMo}_{0.65} \mathrm{Ni}_{0.35} \mathrm{O}_{6-\delta}$ ) [22] and $\mathrm{Lv}$ et al. (CoFe exsolution on $\left.\mathrm{Sr}_{2}\left(\mathrm{Fe}_{1.35} \mathrm{Mo}_{0.45} \mathrm{Co}_{0.2}\right)_{1-\mathrm{z}} \mathrm{O}_{6-\delta}\right)$ [28], in which the Ruddlesden-Popper phase appeared after $10 \mathrm{~h}$ and $4 \mathrm{~h}$ treatment, respectively. Third, the presence of a $\mathrm{Fe}-\mathrm{Ni}$ alloy with composition $\mathrm{FeNi}_{3}$ (cubic, ICSD 5116, space group, $\mathrm{Pm}-3 \mathrm{~m}$ ) was detected, with the main reflections appearing at $2 \theta=44.0$ and $51.3^{\circ}$. For the sake of comparison, the main XRD reflections of Fe and Ni metal are plotted in Figure 5a, which did not correspond to any of the peaks present in the SFNM65 material after $20 \mathrm{~h}$ exsolution treatment. The detection of the alloy phase was possible by the larger particle size obtained after using a more prolonged treatment ( $20 \mathrm{~h}$ instead of $2 \mathrm{~h}$ ). As observed in Figure $5 \mathrm{~b}$, the longer exsolution treatment time resulted in larger nanoparticles, with a particle size of $65 \mathrm{~nm}$, although particles as large as $110 \mathrm{~nm}$ were also observed, which facilitated the detection of the exsolved alloy phase by XRD. Although the goal of this treatment was to determine the composition of the exsolved alloy nanoparticles, it also provided information about the effects of prolonged exsolution treatment on the particle size, and eventually on the perovskite backbone stability. Here, it is shown that the particle size can be modified by exposing the materials to more prolonged times, however, it results in larger particles, and, especially, in a phase transition of the perovskite backbone, which might have detrimental effects on the catalytic activity. Our results, however, are in contrast with Wang et al., who did not observe particle size enlargement when increasing the treatment time from 3 to $40 \mathrm{~h}$ in humidified $\mathrm{H}_{2}$ at $800{ }^{\circ} \mathrm{C}$ using $\mathrm{Sr}_{2} \mathrm{Fe}_{1.3} \mathrm{Ni}_{0.2} \mathrm{Mo}_{0.5} \mathrm{O}_{6-\delta}$ sintered bars (exsolution of $26 \mathrm{~nm}$ $\mathrm{Fe}-\mathrm{Ni}$ alloys) [23]. Probable causes from the discrepancies of both works can arise from differences in the materials' composition and processing. The use of dense sintered bars could affect the mechanism of nanoparticle growth, since it has been shown that smaller grain sizes could favor the exsolution extent [36]. 

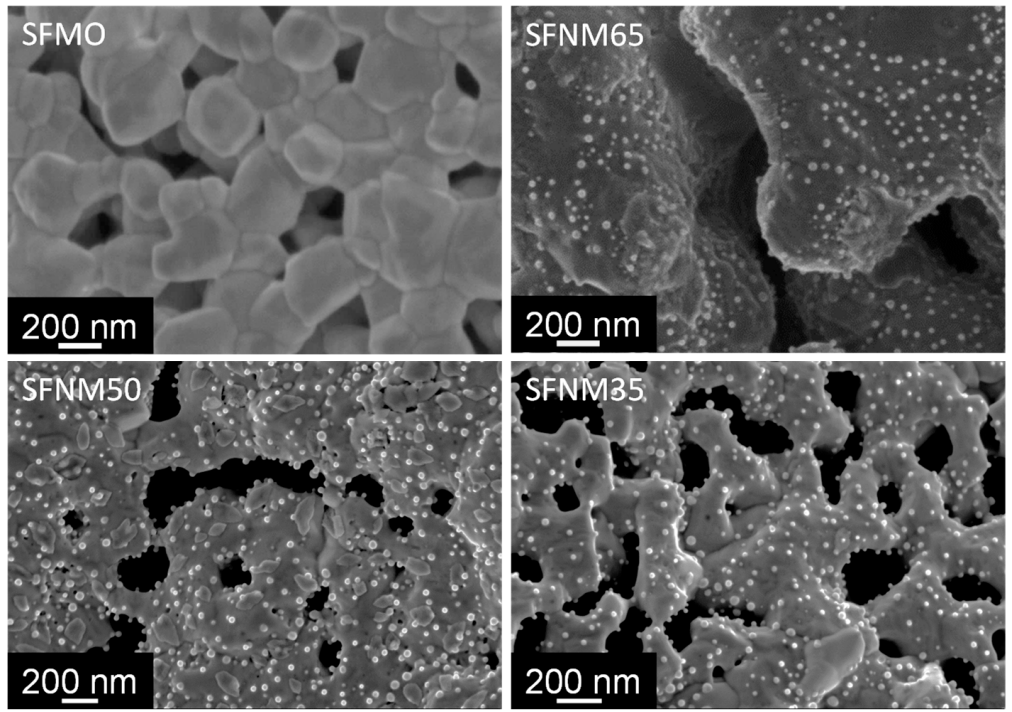

Figure 3. SEM micrographs of the $\mathrm{Sr}_{2} \mathrm{Fe}_{\mathrm{x}} \mathrm{Ni}_{1-\mathrm{x}} \mathrm{MoO}_{6-\delta}$ materials after the exsolution process carried out at $900{ }^{\circ} \mathrm{C}$ for $2 \mathrm{~h}$ under a $5 \% \mathrm{H}_{2}$ atmosphere.
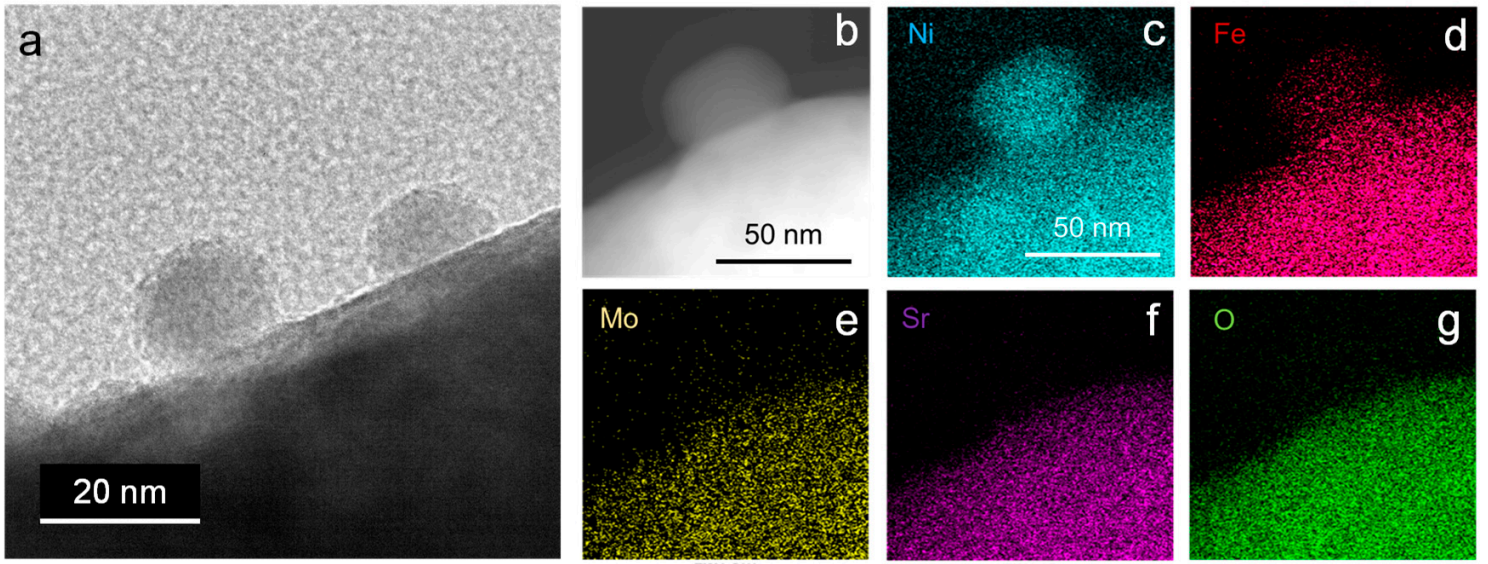

Figure 4. (a) TEM image of the SFNM65 material after $2 \mathrm{~h}$ exsolution at $900{ }^{\circ} \mathrm{C}$ under $5 \% \mathrm{H}_{2}$, depicting the exsolved nanoparticles. (b) HAADF-STEM image of SFNM65 (c-g) EDX mapping images for Ni, Fe, Mo, Sr, and O, respectively, showing that the exsolved nanoparticles are just composed by Fe and Ni.
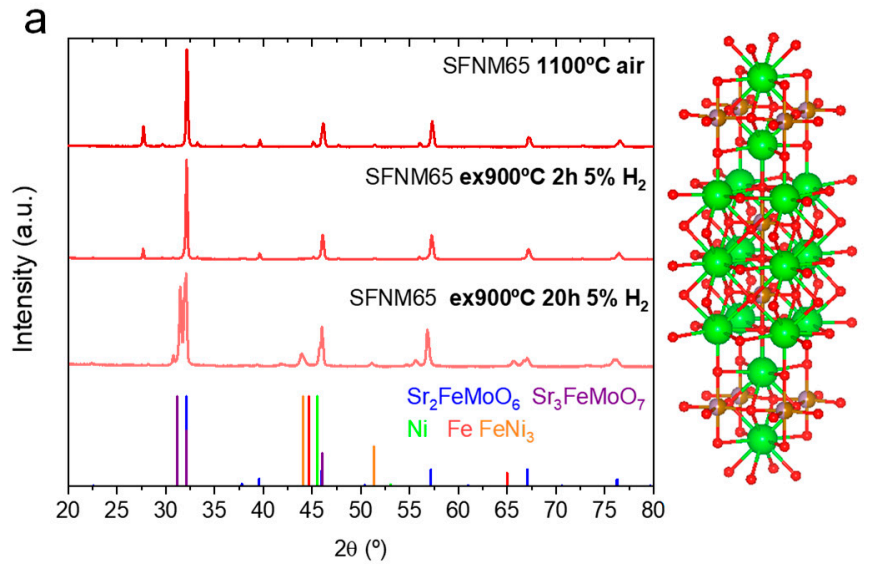

b

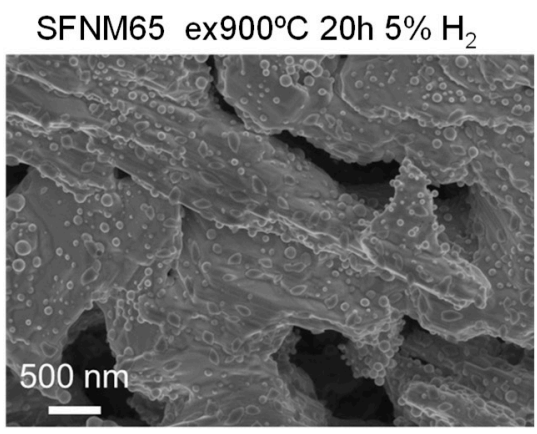

Figure 5. (a) Comparative of the XRD patterns of the SFNM65 material as-synthesized, and after $2 \mathrm{~h}$ and $20 \mathrm{~h}$ exsolution at $900{ }^{\circ} \mathrm{C}$ in a $5 \% \mathrm{H}_{2}$ atmosphere. Crystal structure of a $\mathrm{Sr}_{3} \mathrm{FeMoO}_{7}$ Ruddlesden-Popper phase. Green, brown, and red spheres represent $\mathrm{Sr}, \mathrm{Fe} / \mathrm{Mo}$, and oxygen atoms, respectively. Structure drawn with VESTA [37]. (b) SEM image of the SFNM65 material after $20 \mathrm{~h}$ exsolution. Fe and Ni reflections are shown in (a) for the sake of comparison. 
An alternative way to tune the particle size in exsolution is with temperature [12,34,35,38]. In order to explore this aspect, we treated the double layer perovskite materials at 700 and $800{ }^{\circ} \mathrm{C}$ and compared them with the original exsolution temperature, $900{ }^{\circ} \mathrm{C}$. As observed in Figure 6a, there were remarkable differences on the exsolved nanoparticle sizes when lowering the temperature. Namely, the exsolved nanoparticle sizes $\left(d_{50}\right)$ were $15.6 \pm 4.6,24.4 \pm 5.4$, and $31.0 \pm 8.4 \mathrm{~nm}$ at 600,700 , and $900{ }^{\circ} \mathrm{C}$, respectively. The monotonic increase in the particle size with temperature observed in this work was in line with previous reports that indicate, based on the nucleation theory, that increasing the temperature particularly affects the particle growth [12]. It can also be observed that lowering the temperature $\left(700^{\circ} \mathrm{C}\right)$ resulted in a more uniform particle size distribution, whereas at $900{ }^{\circ} \mathrm{C}$, the distribution was much wider (Figure $6 \mathrm{~b}$ ). On the other hand, we did not observe a clear trend when analyzing the effect of temperature in the exsolved particle population (Figure 6c). The treatment at $700{ }^{\circ} \mathrm{C}$ resulted in a particle population of $84 \mu \mathrm{m}^{-2}$, which decreased at $800{ }^{\circ} \mathrm{C}\left(59 \mu \mathrm{m}^{-2}\right)$ and reached a maximum value at $900{ }^{\circ} \mathrm{C}$ $\left(88 \mu^{-2}\right)$. In other perovskite oxide systems, especially the widely studied $\mathrm{Ni}$ exsolution on titanates, the increase in temperature leads to an increase in particle size and a decrease in nanoparticle dispersion [12,34]. Interestingly, in the $\mathrm{Sr}_{2} \mathrm{Fe}_{x} \mathrm{Ni}_{1-\mathrm{x}} \mathrm{MoO}_{6-\delta}$ system studied here, the standard treatment performed initially $\left(900^{\circ} \mathrm{C}, 2 \mathrm{~h}\right)$ led to the highest degree of nanoparticle dispersion (also observed in SFNM35 and SFNM65, Figure 3).

a

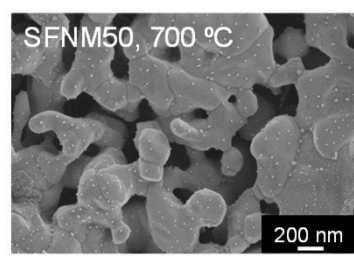

b

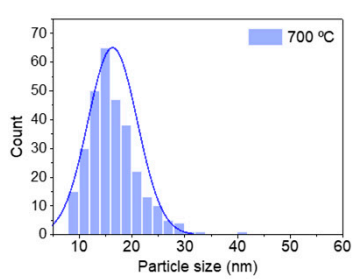

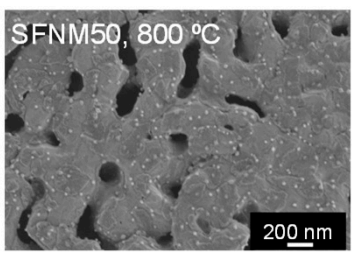

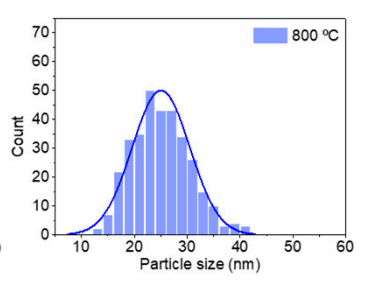

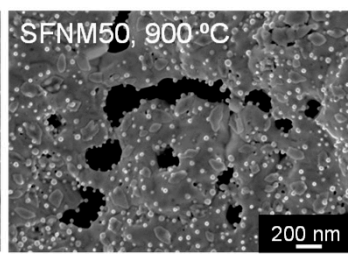

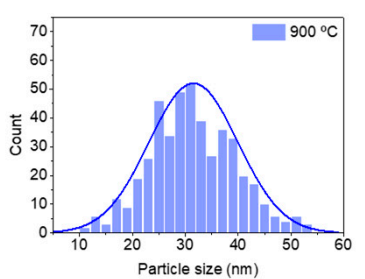

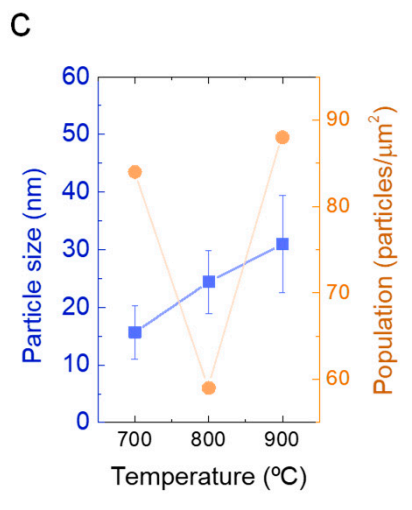

Figure 6. Influence of exsolution temperature on the particle size and population. (a) SEM images of SFNM50 material after exsolution at 700,800 , and $900{ }^{\circ} \mathrm{C}$ during $2 \mathrm{~h}$ in a $5 \% \mathrm{H}_{2}$ atmosphere. (b) Particle size distribution histograms. (c) Particle size and population versus temperature.

In summary, throughout this section, the effect that extrinsic (temperature, time) and intrinsic (B-site composition) factors have on the nanoparticle exsolution in $\mathrm{Sr}_{2} \mathrm{Fe}_{\mathrm{x}} \mathrm{Ni}_{1-\mathrm{x}} \mathrm{MoO}_{6-\delta}$ double-layer perovskites was studied. We confirmed nanoparticle exsolution of an alloy composition of $\mathrm{FeNi}_{3}$. Additionally, in the absence of Ni (i.e., SFMO sample), metallic exsolution was not observed. Increasing exsolution time and temperature led to larger particles, and, in the case of the former, also to a major phase transformation into a Ruddlesden-Popper phase.

\subsection{Dry Reforming Tests on Fe-Ni Alloy Exsolved Nanoparticles}

In the previous section, we showed that by appropriately selecting the reductive treatment conditions, it is possible to tune the exsolved nanoparticle size and dispersion. Regarding the time, the shortest treatment of $2 \mathrm{~h}$ led to the optimum results in terms of particle size and perovskite-backbone stability. In the case of temperature, the smallest particles were obtained at $700^{\circ} \mathrm{C}$ (ca. $15 \mathrm{~nm}$ ), whereas the highest dispersion was observed at $900{ }^{\circ} \mathrm{C}\left(87 \mu \mathrm{m}^{-2}, d_{50} \sim 31 \mathrm{~nm}\right)$. Although materials with smaller nanoparticles will be ideally preferred for the catalysis, the reaction process temperature adds some restrictions to the exsolution temperature. Even if exsolution is known to alleviate particle sintering, it is not advisable to perform nanoparticle exsolution at temperatures lower than the reaction 
temperature, since the particles could eventually grow, even if anchored, during the reaction, resulting in variations in the catalytic activity. For the catalytic test, the temperature of choice was $850^{\circ} \mathrm{C}$, since it is the optimal temperature for dry reforming of methane [3]. Due to the endothermic nature of the reaction, lowering the process temperature will decrease the equilibrium conversion [8]. Thus, the materials used for the dry reforming test were treated at $900{ }^{\circ} \mathrm{C}$ for $2 \mathrm{~h}$ in a $5 \% \mathrm{H}_{2}$ atmosphere in order to drive the exsolution (Figure 3).

The dry reforming catalytic tests were performed in a fixed bed quartz reactor. The exsolution-treated samples were heated in an Ar atmosphere up to $850{ }^{\circ} \mathrm{C}$, the temperature at which the dry reforming reaction was performed for $10 \mathrm{~h}$. The main goals of these catalytic tests were two-fold. First, to evaluate the catalytic activity of the four synthesized samples to ascertain the possible structure-activity relationships derived from the different compositions of the B-site sublattice (i.e., different $\mathrm{Fe} / \mathrm{Ni}$ ratios). Second, to determine the stability of the exsolved nanoparticles after $10 \mathrm{~h}$ under dry reforming conditions at $850{ }^{\circ} \mathrm{C}$. Here, we would like to note that our experiments were carried out with dilute streams of $\mathrm{CH}_{4}$ and $\mathrm{CO}_{2}$ to facilitate the screening of our materials. Ideally, pure streams of $\mathrm{CH}_{4}$ and $\mathrm{CO}_{2}$ will be used in industrial operation.

Figure 7a,b show the $\mathrm{CO}_{2}$ and $\mathrm{CH}_{4}$ conversion $\left(\mathrm{X}_{\mathrm{CO} 2}\right.$ and $\left.\mathrm{X}_{\mathrm{CH} 4}\right)$ versus time for the four samples, respectively. Regarding the $X_{\mathrm{CO} 2}$, it can be observed that, overall, for the four samples, it was stable during the $10 \mathrm{~h}$ test excluding the first injection. From the four samples tested, SFNM50 showed the highest decay in $X_{\mathrm{CO} 2}$ going from $72 \%$ (second injection) to ca. $70 \%(10 \mathrm{~h})$. For SFMO and SFM35, the $\mathrm{CO}_{2}$ conversion slightly increased during the first $2 \mathrm{~h}$ of reaction. SFNM35 and SFNM50 showed the highest $\mathrm{CO}_{2}$ conversion values, which progressively decay with lowering the Ni content. In Figure $7 \mathrm{c}$, the $X_{\mathrm{CO} 2}$ after $10 \mathrm{~h}$ is shown and plotted versus the $\mathrm{Ni}$ content. The $\mathrm{X}_{\mathrm{CO} 2}$ values with decreasing $\mathrm{Ni}$ content in $\mathrm{Sr}_{2} \mathrm{Fe}_{\mathrm{x}} \mathrm{Ni}_{1-\mathrm{x}} \mathrm{MoO}_{6-\delta}$ were 72, 70, 64, and $45 \%$ for $\mathrm{x}=0.65,0.5,0.35$, and 0 , respectively. A similar trend was observed for the $\mathrm{CH}_{4}$ conversion in Figure $7 \mathrm{~b}$, although the overall conversion values were lower than for $\mathrm{CO}_{2}$. After $10 \mathrm{~h}$, the $\mathrm{X}_{\mathrm{CH} 4}$ values with decreasing Ni content were $47,43,37$, and $26 \%$ for $x=0.65,0.5,0.35$, and 0 , respectively. In terms of stability, the SFNM50 exhibited a progressive decay on its $\mathrm{X}_{\mathrm{CH} 4}$ values, which limits its further applicability, which went from 52 to $43 \%$ in $10 \mathrm{~h}$ on stream. For all the samples tested, $\mathrm{CO}_{2}$ conversion was higher than $\mathrm{CH}_{4}$ conversion. This fact resulted in $\mathrm{H}_{2} / \mathrm{CO}$ ratios below the stoichiometric value (Figure 7c), which according to Equation (1), should be equal to 1 . This is caused by the competing reverse water-gas shift reaction (Equation (2)). Regarding the $\mathrm{H}_{2} / \mathrm{CO}$ ratios, the trends are analogous to the $\mathrm{CO}_{2}$ and $\mathrm{CH}_{4}$ conversion, being the highest value achieved $\left(\mathrm{H}_{2} / \mathrm{CO}=0.49\right)$ for the sample with the highest Ni content, SNM35 (Figure $7 \mathrm{c}) . \mathrm{H}_{2}\left(\mathrm{~S}_{\mathrm{H} 2}\right)$ and $\mathrm{CO}$ selectivity $\left(\mathrm{S}_{\mathrm{CO}}\right)$ are depicted in Figure S2 (Supplementary Materials). The values, taken at the end of the reaction, show that both parameters increase with increasing Ni content. Namely, SFMO showed ca. 20\% selectivity toward CO production, whereas for SFNM35 (the highest Ni content), $S_{C O}$ was around $52 \%$. As expected from the $\mathrm{H}_{2} / \mathrm{CO}$ ratios lower than $1, S_{\mathrm{CO}}$ values were higher than $S_{H 2}$. For instance, $\mathrm{H}_{2}$ selectivity for SFNM35 was ca. $32 \%$.

$$
\mathrm{H}_{2}+\mathrm{CO}_{2} \leftrightarrow \mathrm{CO}+\mathrm{H}_{2} \mathrm{O}
$$

To check the stability of the exsolved nanoparticles, the four samples were analyzed by SEM after the $10 \mathrm{~h}$ dry reforming reaction test (Figure $8 \mathrm{a}$ ). It can be observed that the three samples that presented nanoparticle exsolution before the reaction (those with $\mathrm{Ni}$ on B-site) also exhibited exsolved nanoparticles after the $10 \mathrm{~h}$ of the dry reforming test at $850{ }^{\circ} \mathrm{C}$. Through image analyses of the materials after the reaction, we observed that the particle size values were in the range of the values obtained before the reaction. This result emphasizes the robustness of nanoparticles created by the exsolution method. For instance, the SFNM50 material showed exsolved nanoparticles of $\sim 31 \mathrm{~nm}$ before (Figure 6c) and after the reaction (Figure 7c), maintaining the initial values. SFNM35 and SFNM65 presented nanoparticle sizes of $\sim 29$ and $26 \mathrm{~nm}$ after the reaction, which in both cases were lower than SFNM50. The exsolved nanoparticle dispersion after the reaction is shown in Figure 7c. The observed trend indicates that the amount of exsolved 
nanoparticles increased with the $\mathrm{Ni}$ content. Namely, the nanoparticle population was 51, 70, and $85 \mu^{-2}$ for SFNM65, SFNM50, and SFNM35, respectively. Interestingly, SFNM50 showed a nanoparticle population of $88 \mu \mathrm{m}^{-2}$ before the reaction (Figure $6 \mathrm{c}$ ), which decreased to $70 \mu \mathrm{m}^{-2}$ after the reaction. This decay on the nanoparticle dispersion correlates well with the decay in the catalytic activity by SFNM50, especially observed for the $\mathrm{CH}_{4}$ conversion (Figure $7 \mathrm{~b}$ ). In addition, the SFNM50 image after the reaction depicted in Figure 8 revealed the appearance of a major phase segregation that was not observed before the reaction (Figure 3). The formation of this additional phase (characterized by its darker color) could be the responsible for the decay on the nanoparticle population after reaction. As observed in the SEM image (Figure 8), this segregated phase did not exhibit nanoparticle exsolution. XRD was utilized to confirm the nature of this phase. Figure $8 \mathrm{~b}$ shows the XRD patterns of the four samples after the dry reforming reaction tests. The main impurity corresponds to $\mathrm{SrMoO}_{4}$, which was present on the as-synthesized materials (Figure 2a), disappeared after the exsolution treatment (Figure 2b), and regenerated during the $10 \mathrm{~h}$ dry reforming test. In addition, we identified the presence of $\mathrm{SrCO}_{3}$ signatures at $2 \theta=25-26^{\circ}$ (Figure $8 b$ ) as a consequence of the reaction of $\mathrm{Sr}^{2+}$ with the $\mathrm{CO}_{2}$ used for the dry reforming tests. Carbonation of A-site cations in perovskites (e.g., $\mathrm{Sr}, \mathrm{Ca}, \mathrm{Ba}$ ) is known to be a major issue in several $\mathrm{CO}_{2}$ valorization processes [39,40], although for most of the samples, its presence was negligible. The material that was more affected by $\mathrm{Sr}$ carbonation was SFNM50. The concentration of impurity phases after the reaction was determined by Rietveld refinement, indicating a $7.9 \%$ of $\mathrm{SrCO}_{3}$ in SFNM50 material after the reaction. Furthermore, it showed $51.6 \%$ of $\mathrm{SrMoO}_{4}$, making SFNM50 the sample in which the double perovskite phase, which supports the exsolved nanoparticles, was more degraded after the dry reforming test. This fact had strong implications on the exsolved nanoparticle dispersion, since $\mathrm{SrMoO}_{4}$ and $\mathrm{SrCO}_{3}$ were not expected to allocate Ni and/or Fe cations in their crystal lattices, thus, limiting the amount of available surface with the presence of alloy nanoparticles. In particular, the exsolved nanoparticle dispersion of SFNM50 decreased from 88 particles $\mu \mathrm{m}^{-2}$ (Figure 6c) to 70 particles $\mu \mathrm{m}^{-2}$ (Figure 7c). The combination of both facts, the appearance of the $\mathrm{SrMoO}_{4}$ segregated phase and the decrease in the nanoparticle dispersion, might be responsible for the progressive decay in the SFNM50 $\mathrm{CH}_{4}$ conversion observed in Figure $7 \mathrm{~b}$. In the case of SFNM35, such decay was more attenuated, which could correlate well with a lower amount of detected phase segregation after reaction. Namely, SFNM35 exhibited 3.9\% and 44.3\% for the $\mathrm{SrCO}_{3}$ and $\mathrm{SrMoO}_{4}$ impurity phases, respectively. Interestingly, samples SFMO and SFM65, which exhibited lower $\mathrm{CH}_{4}$ and $\mathrm{CO}_{2}$ conversion values, presented minor contributions of the phase segregation after the reaction. For instance, SFMO showed a negligible presence of $\mathrm{SrCO}_{3}(0.1 \%)$ and $27.8 \%$ of $\mathrm{SrMoO}_{4}$, with the latter in the concentration range detected before the reaction (Table 1). Next, we conducted Raman spectroscopy to analyze the possible formation of carbon deposits during the $10 \mathrm{~h}$ reaction test. Figure $8 \mathrm{c}$ shows the Raman spectra of the four samples after the reaction, depicting the $1000-2500 \mathrm{~cm}^{-1}$ wavenumber region, in which modes related to carbon species are expected to appear. Namely, the D and G bands were located at 1368 and $1560 \mathrm{~cm}^{-1}$, respectively [41]. Only a minor contribution of the mode at around $1560 \mathrm{~cm}^{-1}$ (ascribed to the G band) was observed for the samples SFNM50 and SFNM65, whereas no modes related to carbon deposition were observed for SFNM35, confirming the high resistance to coking obtained with the exsolution method [7]. With these postmortem analyses, we can conclude that the morphological changes suffered by the materials were mostly related with phase segregations occurring in the host perovskite matrix, whereas the exsolved nanoparticles exhibited high stability, which were responsible for an increase in the catalytic activity. It was observed that a higher $\mathrm{Ni} / \mathrm{Fe}$ ratio favors a higher population of $\mathrm{FeNi}_{3}$ nanoparticles, ascribed to the thermodynamically favorability for $\mathrm{Ni}$ cations to exsolve over Fe cations, resulting in these Ni rich metallic alloys. Nonetheless, even if the nanoparticles retain its initial particle size and level of anchoring, the presence of phase segregations alter the nanoparticle population if, as was the case here, the segregations do not allocate exsolved nanoparticles. This fact caused a decrease in the $\mathrm{CH}_{4}$ conversion for 
the SFM50 sample (Figure 7b), which is the material that presented the highest presence of phase impurities $\left(\mathrm{SrCO}_{3}\right.$ and $\left.\mathrm{SrMoO}_{4}\right)$ after the reaction (Figure 8b). Eventually, this issue could be tackled by designing perovskite compositions with A-site deficiency and with a higher $\mathrm{Fe}(\mathrm{Ni}) / \mathrm{Mo}$ ratio on the B-site. In this case, A-site deficiency could favor a higher extent of nanoparticle exsolution.

a

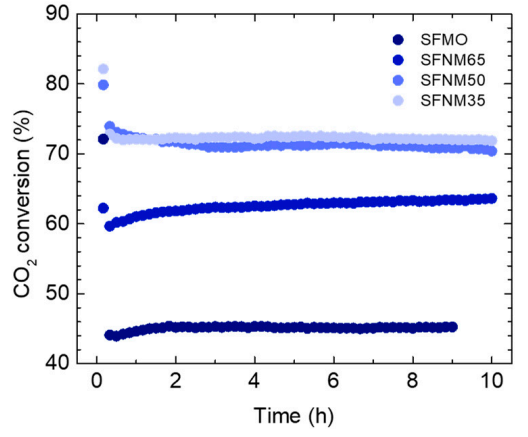

C

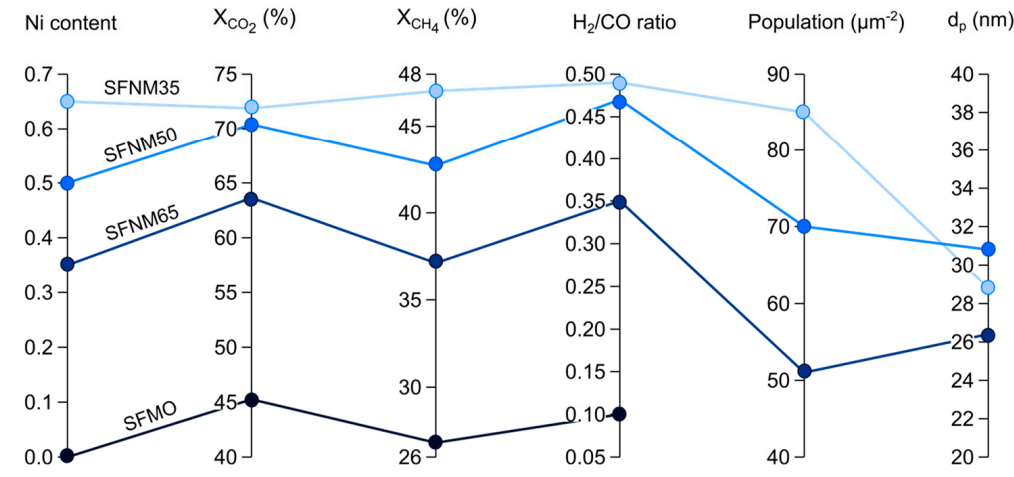

b

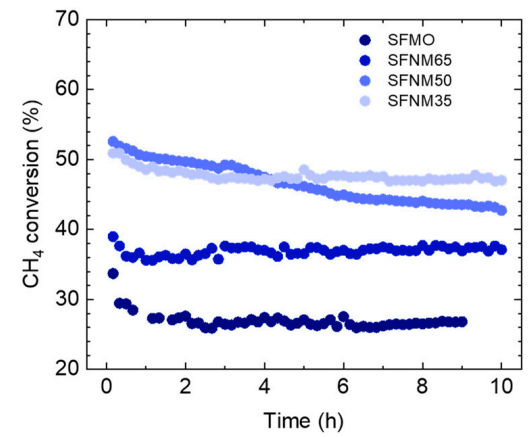

$(\mathrm{nm})$

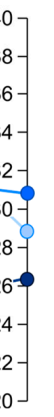

Figure 7. (a) $\mathrm{CO}_{2}\left(\mathrm{X}_{\mathrm{CO} 2}\right)$ and (b) $\mathrm{CH}_{4}$ conversion $\left(\mathrm{X}_{\mathrm{CH} 4}\right)$ for the dry reforming reaction tests carried out at $850{ }^{\circ} \mathrm{C}$, during $10 \mathrm{~h}$ in a fixed bed quartz tube reactor. $\mathrm{CO}_{2}: \mathrm{CH}_{4}: \mathrm{Ar}, 5: 5: 90, \mathrm{SV}=24 \mathrm{~L} \mathrm{~g}_{\mathrm{cat}}{ }^{-1} \mathrm{~h}^{-1}$ (c) Composition-structure-performance comparative of Ni content, $\mathrm{CO}_{2}$, and $\mathrm{CH}_{4}$ conversion, and $\mathrm{H}_{2} / \mathrm{CO}$ ratio at $10 \mathrm{~h}$ dry reforming test, nanoparticle population, and exsolved nanoparticle size $\left(d_{p}\right)$.

a

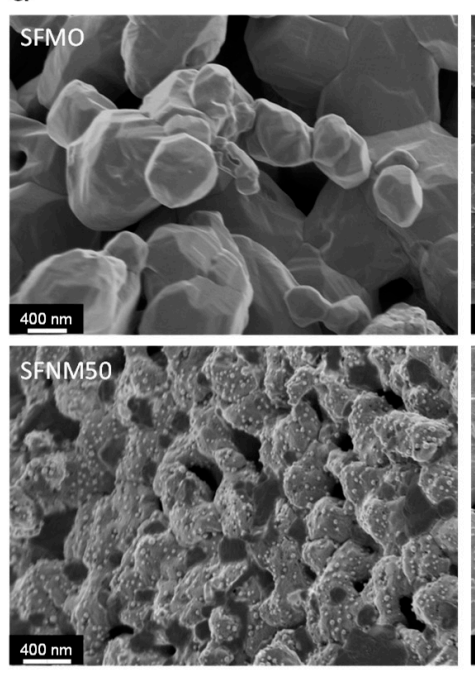

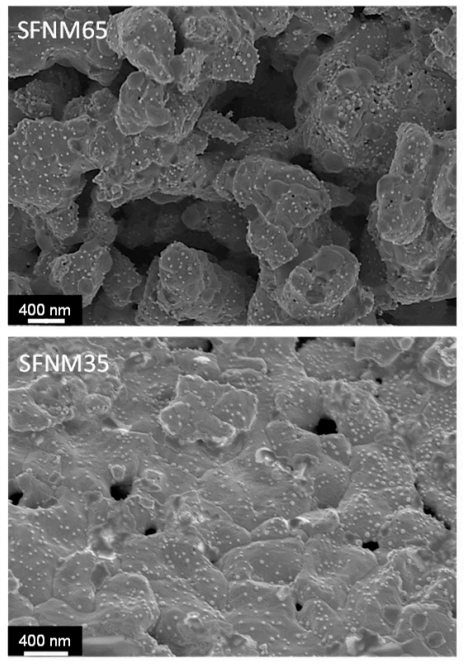

b
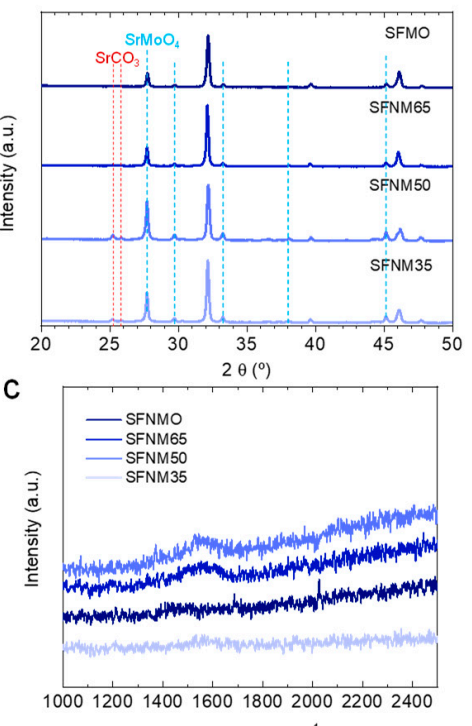

Figure 8. (a) SEM images, (b) XRD patterns, and (c) Raman spectra of the four $\mathrm{Sr}_{2} \mathrm{Fe}_{\mathrm{X}} \mathrm{Ni}_{1-\mathrm{x}} \mathrm{MoO}_{6-\delta}$ samples after the reaction $\left(850{ }^{\circ} \mathrm{C}, 10 \mathrm{~h}, 5 \%\right.$ vol. $\mathrm{CO}_{2}, 5 \%$ vol. $\mathrm{CH}_{4}, 100 \mathrm{~mL} \mathrm{~min}^{-1}$ of total flow). Figure (c) depicts the $1000-2500 \mathrm{~cm}^{-1}$ region to show the modes associated with carbon deposition. 


\section{Conclusions}

In this work, we investigated the influence that extrinsic (time, temperature) and intrinsic (B-site composition) factors had on the exsolution of $\mathrm{Fe}-\mathrm{Ni}$ alloys in $\mathrm{Sr}_{2} \mathrm{Fe}_{\mathrm{x}} \mathrm{Ni}_{1-\mathrm{x}} \mathrm{MoO}_{6-\delta}$ double-layer perovskite materials, and eventually, to its catalytic activity in the dry reforming of methane. Our results indicate that a higher Ni content facilitates the exsolution, illustrated by higher values of nanoparticle population for Ni-rich compositions and the absence of nanoparticle exsolution on the $\mathrm{Sr}_{2} \mathrm{FeMoO}_{6}$ sample. These results connect well with literature reports that indicate that $\mathrm{Ni}$ has more favorable thermodynamics to exsolve than Fe. This fact might be the reason behind obtaining a Ni-rich alloy composition $\left(\mathrm{FeNi}_{3}\right)$ after exsolution, as observed by EDX and XRD. The evaluation of the extrinsic factors pointed to larger nanoparticles with increasing temperature and time, and in the latter case, to a crystallographic phase transition in which a Ruddlesden-Popper phase is predominant. Dry reforming tests indicate that increasing $\mathrm{Ni} / \mathrm{Fe}$ ratio in the B-site favored both $\mathrm{CO}_{2}$ and $\mathrm{CH}_{4}$ conversion, which was ascribed to a higher nanoparticle population obtained with higher Ni content. The nanoparticle size (ca. $30 \mathrm{~nm}$ ) was remarkably stable after the $10 \mathrm{~h}$ dry reforming reaction, corroborating the benefits of exsolution in high temperature thermochemical processes. In addition, Raman spectroscopy illustrated the low tendency to form carbon depositions. However, oxide and carbonate segregations, observed after the catalytic test, caused a decrease in nanoparticle population that especially affected the $\mathrm{CH}_{4}$ conversion in the $\mathrm{Fe} / \mathrm{Ni}=1$ sample. The results presented here illustrate the potential of double-layered perovskites as host for alloy nanoparticle exsolution and its potential use in high temperature thermocatalytic fuel production. Optimization of the perovskite host to avoid phase segregations via A-site deficiency or B-site doping could eventually increase the nanoparticle dispersion and catalytic activity for the dry reforming of methane or other energy related high temperature chemical processes.

\section{Materials and Methods}

\subsection{Materials Synthesis}

$\mathrm{Sr}_{2} \mathrm{Fe}_{\mathrm{x}} \mathrm{Ni}_{1-\mathrm{x}} \mathrm{MoO}_{6-\delta}$ materials with $\mathrm{x}=0.35-1$ were synthesized through a modified version of the Pechini method. Metal precursors, $\mathrm{Sr}\left(\mathrm{NO}_{3}\right)_{2}, 99 \%$, Sigma Aldrich (St. Louis, MO, USA); $\mathrm{Fe}\left(\mathrm{NO}_{3}\right)_{3} \cdot 9 \mathrm{H}_{2} \mathrm{O}\left(98 \%\right.$, Sigma Aldrich); $\mathrm{H}_{24} \mathrm{Mo}_{7} \mathrm{~N}_{6} \mathrm{O}_{24} \cdot 4 \mathrm{H}_{2} \mathrm{O}$ (98\%, Sigma Aldrich); and $\mathrm{Ni}\left(\mathrm{NO}_{3}\right)_{2} \cdot 6 \mathrm{H}_{2} \mathrm{O}(98 \%$, Sigma Aldrich) were dissolved in deionized water and mixed with citric acid, CA ( $99 \%$, Sigma Aldrich-Merck) at $60{ }^{\circ} \mathrm{C}$ under constant stirring during $3 \mathrm{~h}$, using a metal precursor:CA molar ratio of 1:1.5 Afterward, ethylene glycol, EG, (99\%, Sigma Aldrich-Merck) was added to the mixture and the temperature was increased to $80^{\circ} \mathrm{C}$ for $2 \mathrm{~h}$, with a CA:EG ratio of $2 / 3 \mathrm{wt} \%$. After most of the solution was evaporated, it was transferred to a drying oven and heated at $220^{\circ} \mathrm{C}$ overnight, a process in which gelification and calcination of the gel took place. Then, the dry powders were ground into fine powders with an agate mortar and calcined at $1100{ }^{\circ} \mathrm{C}$ for $10 \mathrm{~h}$ to obtain the double-perovskite phase. Nanoparticle exsolution was carried out in a horizontal tubular furnace at $900{ }^{\circ} \mathrm{C}$ for $2 \mathrm{~h}$ under a $5 \% \mathrm{H}_{2} /$ Ar flow, unless otherwise specified in the text.

\subsection{Physicochemical Characterization}

X-ray diffractometry (XRD) was performed utilizing a PANalytical CubiX fast diffractometer(Almelo, The Netherlands)using $\mathrm{CuK} \alpha 1,2$ radiation and a $X^{\prime}$ Celerator detector in Bragg-Brentano geometry. XRD patterns were recorded in the $2 \theta$ range $20^{\circ}$ to $70^{\circ}$ and analyzed using the software $X^{\prime}$ Pert Highscore Plus (Almelo, The Netherlands). In-situ XRD tests were carried out in an Anton Paar XRK-900 reaction chamber attached to the diffractometer. Raman spectroscopy was performed with a Renishaw Raman spectrometer (New Mills, UK). Analyses were conducted at room temperature with a $514 \mathrm{~nm}$ laser equipped with an Olympus microscope and a CCD detector.

The morphology of the synthesized oxides was analyzed via scanning electron microscopy (SEM) with a GeminiSEM 500 from Zeiss (Oberkochen, Germany) and transmission electron microscopy (TEM) with a JEM 2100F (JEOL Ltd., Tokyo, Japan) 200 kV 
field emission microscope equipped with a Gatan OneView camera. Energy dispersive X-ray spectroscopy elemental point scan analyses were conducted on a EDS X-Max 80 de Oxford Instruments (High Wycombe, UK), with a $127 \mathrm{eV}$ resolution. Nanoparticle size and distribution were obtained through image analyses using ImageJ software (Version 1.53j, NIH, USA) [42].

\subsection{Dry Reforming of Methane Reaction Tests}

Dry reforming of methane was carried out in a fixed-bed reactor setup. The reactor consisted of a quartz tube of a $\frac{1}{2}$ inch inner diameter placed inside a tubular vertical electrical furnace. The oxide samples $(0.25 \mathrm{~g})$ were placed over a quartz frit located at half of the quartz tube (total length $41 \mathrm{~cm}$ ). Temperature was controlled with a K-type thermocouple in contact with the oxide bed and covered by a quartz shield. For the reaction tests, the materials were pressed into pellets, crushed, and sieved in 200-400 $\mu \mathrm{m}$ sieves. In a typical experiment, the temperature was raised to $850{ }^{\circ} \mathrm{C}$ under an $\operatorname{Ar}$ (Praxair) atmosphere $\left(100 \mathrm{~mL} \mathrm{~min}^{-1}\right)$. Then, $\mathrm{CH}_{4}$ and $\mathrm{CO}_{2}$ were injected with a total flow of $100 \mathrm{~mL} \mathrm{~min}^{-1}$, with a volume fraction $\mathrm{CH}_{4}: \mathrm{CO}_{2}$ :Ar ratio of 5:5:90 and a hourly space velocity of $24 \mathrm{~L} \mathrm{~g}^{-1} \mathrm{~h}^{-1}$. The gas bottles were of $10 \% \mathrm{CH}_{4}$ balanced in $\mathrm{Ar}$ and $15 \% \mathrm{CO}_{2}$ balanced in Ar. Gas outlet was analyzed by using a Micro-GC CP-4900 (Varian, Santa Clara, CA, USA) gas chromatograph equipped with Molsieve5A and PoraPlot-Q glass capillary modules. $\mathrm{CH}_{4}$ $\left(X_{\mathrm{CH}_{4}}\right)$ and $\mathrm{CO}_{2}\left(\mathrm{X}_{\mathrm{CO} 2}\right)$ conversion and $\mathrm{CO}\left(\mathrm{S}_{\mathrm{CO}}\right)$ and $\mathrm{H}_{2}\left(\mathrm{~S}_{\mathrm{H} 2}\right)$ selectivity were determined according to the following equations:

$$
\begin{gathered}
X_{\mathrm{CH}_{4}}=\frac{n_{\mathrm{CH}_{4, \text { in }}}-n_{\mathrm{CH}_{4, \text { out }}}}{n_{\mathrm{CH}_{4, \text { in }}}} \cdot 100 \\
X_{\mathrm{CO}_{2}}=\frac{n_{\mathrm{CO}_{2, \text { in }}}-n_{\mathrm{CO}_{2, \text { out }}}}{n_{\mathrm{CO}_{2, \text { in }}}} \cdot 100 \\
S_{\mathrm{CO}}=\frac{n_{\mathrm{CO}}}{\left(n_{\mathrm{CO}_{2, \text { in }}}-n_{\mathrm{CO}_{2, \text { out }}}\right)+\left(n_{\mathrm{CH}_{4, \text { in }}}-n_{\mathrm{CH}_{4, \text { out }}}\right)} \cdot 100 \\
S_{\mathrm{H}_{2}}=\frac{n_{\mathrm{H}_{2}}}{2 \cdot\left(n_{\mathrm{CH}_{4, \text { in }}}-n_{\mathrm{CH}_{4, \text { out }}}\right)} \cdot 100
\end{gathered}
$$

Supplementary Materials: The following are available online at https:/ /www.mdpi.com/article/10 $.3390 /$ catal11060741/s1, Figure S1: Rietveld refinement exemplified for $\mathrm{Sr}_{2} \mathrm{Fe}_{0.5} \mathrm{Ni}_{0.5} \mathrm{MoO}_{6-\delta}$ material as synthesized (calcination at $1100{ }^{\circ} \mathrm{C}$ in air). Due to Ni doping on B-site there is a shift from the observed data to the reference taken for the double perovskite, $\mathrm{Sr}_{2} \mathrm{FeMoO}_{6}$, Figure: $\mathrm{S} 2 . \mathrm{CO}\left(S_{\mathrm{CO}}\right)$ and $\mathrm{H}_{2}$ selectivity $\left(\mathrm{S}_{\mathrm{H} 2}\right)$ for the four materials, measured at $10 \mathrm{~h}$ on stream. $\left(\mathrm{T}=850^{\circ} \mathrm{C}\right)$.

Author Contributions: Conceptualization, A.J.C. and J.M.S.; Methodology, A.J.C.; Investigation, A.J.C.; Resources, A.J.C. and J.M.S.; Data Curation, A.J.C.; Writing-Original Draft Preparation, A.J.C.; Writing—Review \& Editing, J.M.S.; Supervision, J.M.S.; Project Administration, A.J.C. and J.M.S.; Funding Acquisition, A.J.C. and J.M.S. All authors have read and agreed to the published version of the manuscript.

Funding: The project that gave rise to these results received the support of a fellowship from "la Caixa" Foundation (ID 100010434). The fellowship code is LCF/BQ/PI20/11760015. Additional funding from the Spanish Government (Grant RTI2018-102161) is also acknowledged.

Acknowledgments: A.J.C. is grateful for the help of José Luis Jordá in performing the in situ XRD analysis; Alejandro Gamir with the Rietveld refinements; and Andrés López for performing the XRD analyses after the reaction. We thank the support of the Electronic Microscopy Service of the Universitat Politècnica de València.

Conflicts of Interest: The authors declare no conflict of interest. 


\section{References}

1. Munnik, P.; De Jongh, P.E.; De Jong, K.P. Recent Developments in the Synthesis of Supported Catalysts. Chem. Rev. 2015, 115, 6687-6718. [CrossRef]

2. Hansen, T.W.; DeLaRiva, A.T.; Challa, S.R.; Datye, A.K. Sintering of Catalytic Nanoparticles: Particle Migration or Ostwald Ripening? Acc. Chem. Res. 2013, 46, 1720-1730. [CrossRef]

3. Wang, C.; Wang, Y.; Chen, M.; Liang, D.; Yang, Z.; Cheng, W.; Tang, Z.; Wang, J.; Zhang, H. Recent advances during $\mathrm{CH}_{4}$ dry reforming for syngas production: A mini review. Int. J. Hydrogen Energy 2021, 46, 5852-5874. [CrossRef]

4. Kim, J.H.; Kim, J.K.; Liu, J.; Curcio, A.; Jang, J.; Kim, I.; Ciucci, F.; Jung, W. Nanoparticle Ex-solution for Supported Catalysts: Materials Design, Mechanism and Future Perspectives. ACS Nano 2020. [CrossRef]

5. Zhang, J.; Gao, M.; Luo, J.-L. In Situ Exsolved Metal Nanoparticles: A Smart Approach for Optimization of Catalysts. Chem. Mater. 2020, 32, 5424-5441. [CrossRef]

6. Kousi, K.; Tang, C.; Metcalfe, I.S.; Neagu, D. Emergence and Future of Exsolved Materials. Small 2021, 2006479. [CrossRef]

7. Neagu, D.; Oh, T.S.; Miller, D.N.; Menard, H.; Bukhari, S.M.; Gamble, S.R.; Gorte, R.J.; Vohs, J.M.; Irvine, J.T. Nano-socketed nickel particles with enhanced coking resistance grown in situ by redox exsolution. Nat. Commun. 2015, 6, 8120. [CrossRef] [PubMed]

8. Naeem, M.A.; Abdala, P.M.; Armutlulu, A.; Kim, S.M.; Fedorov, A.; Müller, C.R. Exsolution of Metallic Ru Nanoparticles from Defective, Fluorite-Type Solid Solutions $\mathrm{Sm}_{2} \mathrm{Ru}_{\mathrm{x}} \mathrm{Ce}_{2-\mathrm{x}} \mathrm{O}_{7}$ To Impart Stability on Dry Reforming Catalysts. ACS Catal. 2020, 10, 1923-1937. [CrossRef]

9. Carrillo, A.J.; Navarrete, L.; Laqdiem, M.; Balaguer, M.; Serra, J.M. Boosting methane partial oxidation on ceria through exsolution of robust Ru nanoparticles. Mater. Adv. 2021, 2, 2924-2934. [CrossRef]

10. Bhattar, S.; Abedin, M.A.; Kanitkar, S.; Spivey, J.J. A review on dry reforming of methane over perovskite derived catalysts. Catal. Today 2020. [CrossRef]

11. Sun, X.; Chen, H.; Yin, Y.; Curnan, M.T.; Han, J.W.; Chen, Y.; Ma, Z. Progress of Exsolved Metal Nanoparticles on Oxides as High Performance (Electro)Catalysts for the Conversion of Small Molecules. Small 2021, 2005383. [CrossRef] [PubMed]

12. Otto, S.; Kousi, K.; Neagu, D.; Bekris, L.; Janek, J.; Metcalfe, I.S. Exsolved Nickel Nanoparticles Acting as Oxygen Storage Reservoirs and Active Sites for Redox $\mathrm{CH}_{4}$ Conversion. ACS Appl. Energy Mater. 2019, 2, 7288-7298. [CrossRef]

13. Kousi, K.; Neagu, D.; Bekris, L.; Calì, E.; Kerherve, G.; Papaioannou, E.I.; Payne, D.J.; Metcalfe, I.S. Low temperature methane conversion with perovskite-supported exo/endo -particles. J. Mater. Chem. A 2020, 8, 12406-12417. [CrossRef]

14. Kousi, K.; Neagu, D.; Bekris, L.; Papaioannou, E.I.; Metcalfe, I.S. Endogenous Nanoparticles Strain Perovskite Host Lattice Providing Oxygen Capacity and Driving Oxygen Exchange and $\mathrm{CH}_{4}$ Conversion to Syngas. Angew. Chem. Int. Ed. 2020, 59, 2510-2519. [CrossRef] [PubMed]

15. Carrillo, A.J.; Kim, K.J.; Hood, Z.D.; Bork, A.H.; Rupp, J.L.M. $\mathrm{La}_{0.6} \mathrm{Sr}_{0.4} \mathrm{Cr}_{0.8} \mathrm{Co}_{0.2} \mathrm{O}_{3}$ Perovskite Decorated with Exsolved Co Nanoparticles for Stable $\mathrm{CO}_{2}$ Splitting and Syngas Production. ACS Appl. Energy Mater. 2020, 3, 4569-4579. [CrossRef]

16. Zubenko, D.; Singh, S.; Rosen, B.A. Exsolution of Re-alloy catalysts with enhanced stability for methane dry reforming. Appl. Catal. B Environ. 2017, 209, 711-719. [CrossRef]

17. Papargyriou, D.; Miller, D.N.; Sirr Irvine, J.T. Exsolution of Fe-Ni alloy nanoparticles from $(\mathrm{La}, \mathrm{Sr})(\mathrm{Cr}, \mathrm{Fe}, \mathrm{Ni}) \mathrm{O}_{3}$ perovskites as potential oxygen transport membrane catalysts for methane reforming. J. Mater. Chem. A 2019, 7, 15812-15822. [CrossRef]

18. Joo, S.; Kwon, O.; Kim, K.; Kim, S.; Kim, H.; Shin, J.; Jeong, H.Y.; Sengodan, S.; Han, J.W.; Kim, G. Cation-swapped homogeneous nanoparticles in perovskite oxides for high power density. Nat. Commun. 2019, 10, 1-9. [CrossRef]

19. Kwon, O.; Kim, K.; Joo, S.; Jeong, H.Y.; Shin, J.; Han, J.W.; Sengodan, S.; Kim, G. Self-assembled alloy nanoparticles in a layered double perovskite as a fuel oxidation catalyst for solid oxide fuel cells. J. Mater. Chem. A 2018, 6, 15947-15953. [CrossRef]

20. Wang, H.; Dong, X.; Zhao, T.; Yu, H.; Li, M. Dry reforming of methane over bimetallic Ni-Co catalyst prepared from $\mathrm{La}\left(\mathrm{Co}_{\mathrm{x}} \mathrm{Ni}_{1-\mathrm{x}}\right)_{0.5} \mathrm{Fe}_{0.5} \mathrm{O}_{3}$ perovskite precursor: Catalytic activity and coking resistance. Appl. Catal. B Environ. 2019, 245, 302-313. [CrossRef]

21. Tsoukalou, A.; Imtiaz, Q.; Kim, S.M.; Abdala, P.M.; Yoon, S.; Müller, C.R. Dry-reforming of methane over bimetallic Ni-M/La ${ }_{2} \mathrm{O}_{3}$ $(\mathrm{M}=\mathrm{Co}, \mathrm{Fe})$ : The effect of the rate of $\mathrm{La}_{2} \mathrm{O}_{2} \mathrm{CO}_{3}$ formation and phase stability on the catalytic activity and stability. J. Catal. 2016, 343, 208-214. [CrossRef]

22. Du, Z.; Zhao, H.; Yi, S.; Xia, Q.; Gong, Y.; Zhang, Y.; Cheng, X.; Li, Y.; Gu, L.; Świerczek, K. High-Performance Anode Material $\mathrm{Sr}_{2} \mathrm{FeMo}_{0.65} \mathrm{Ni}_{0.35} \mathrm{O}_{6-\delta}$ with In Situ Exsolved Nanoparticle Catalyst. ACS Nano 2016, 10, 8660-8669. [CrossRef] [PubMed]

23. Wang, Y.; Liu, T.; Li, M.; Xia, C.; Zhou, B.; Chen, F. Exsolved Fe-Ni nano-particles from $\mathrm{Sr}_{2} \mathrm{Fe}_{1.3} \mathrm{Ni}_{0.2} \mathrm{Mo}_{0.5} \mathrm{O}_{6}$ perovskite oxide as a cathode for solid oxide steam electrolysis cells. J. Mater. Chem. A 2016, 4, 14163-14169. [CrossRef]

24. Li, J.; Yu, Y.; Yin, Y.M.; Zhou, N.; Ma, Z.F. A novel high performance composite anode with in situ growth of Fe-Ni alloy nanoparticles for intermediate solid oxide fuel cells. Electrochim. Acta 2017, 235, 317-322. [CrossRef]

25. Zhu, T.; Troiani, H.E.; Mogni, L.V.; Han, M.; Barnett, S.A. Ni-Substituted Sr(Ti,Fe)O ${ }_{3}$ SOFC Anodes: Achieving High Performance via Metal Alloy Nanoparticle Exsolution. Joule 2018, 2, 478-496. [CrossRef]

26. Chang, H.; Chen, H.; Yang, G.; Shi, J.; Zhou, W.; Bai, J.; Wang, Y.; Li, S.D. Enhanced coking resistance of Ni cermet anodes for solid oxide fuel cells based on methane on-cell reforming by a redox-stable double-perovskite $\mathrm{Sr}_{2} \mathrm{MoFeO}_{6-\delta}$. Int. J. Energy Res. 2019, 43, 2527-2537. [CrossRef]

27. Jiang, Y.; Yang, Y.; Xia, C.; Bouwmeester, H.J.M. $\mathrm{Sr}_{2} \mathrm{Fe}_{1.4} \mathrm{Mn}_{0.1} \mathrm{Mo}_{0.5} \mathrm{O}_{6-\delta}$ perovskite cathode for highly efficient $\mathrm{CO}_{2}$ electrolysis. J. Mater. Chem. A 2019, 7, 22939-22949. [CrossRef] 
28. Lv, H.; Lin, L.; Zhang, X.; Song, Y.; Matsumoto, H.; Zeng, C.; Ta, N.; Liu, W.; Gao, D.; Wang, G.; et al. In Situ Investigation of Reversible Exsolution/Dissolution of CoFe Alloy Nanoparticles in a Co-Doped $\mathrm{Sr}_{2} \mathrm{Fe}_{1.5} \mathrm{Mo}_{0.5} \mathrm{O}_{6-\delta}$ Cathode for $\mathrm{CO}_{2}$ Electrolysis. Adv. Mater. 2020, 32, 1906193. [CrossRef] [PubMed]

29. Chen, L.; $\mathrm{Xu}$, J.; Wang, X.; Xie, $\mathrm{K}_{\text {. }} \mathrm{Sr}_{2} \mathrm{Fe}_{1.5+\mathrm{x}} \mathrm{Mo}_{0.5} \mathrm{O}_{6-\delta}$ cathode with exsolved Fe nanoparticles for enhanced $\mathrm{CO}_{2}$ electrolysis. Int. J. Hydrogen Energy 2020, 45, 11901-11907. [CrossRef]

30. Meng, X.; Wang, Y.; Zhao, Y.; Zhang, T.; Yu, N.; Chen, X.; Miao, M.; Liu, T. In-situ exsolution of nanoparticles from Ni substituted $\mathrm{Sr}_{2} \mathrm{Fe}_{1.5} \mathrm{Mo}_{0.5} \mathrm{O}_{6}$ perovskite oxides with different Ni doping contents. Electrochim. Acta 2020, 348, 136351. [CrossRef]

31. Zhu, K.; Wu, T.; Li, M.; Lu, R.; Zhu, X.; Yang, W. Perovskites decorated with oxygen vacancies and Fe-Ni alloy nanoparticles as high-efficiency electrocatalysts for the oxygen evolution reaction. J. Mater. Chem. A 2017, 5, 19836-19845. [CrossRef]

32. Lv, H.; Lin, L.; Zhang, X.; Gao, D.; Song, Y.; Zhou, Y.; Liu, Q.; Wang, G.; Bao, X. In situ exsolved FeNi 3 nanoparticles on nickel doped $\mathrm{Sr}_{2} \mathrm{Fe}_{1.5} \mathrm{Mo}_{0.5} \mathrm{O}_{6-\delta}$ perovskite for efficient electrochemical $\mathrm{CO}_{2}$ reduction reaction. J. Mater. Chem. A 2019, 7, 11967-11975. [CrossRef]

33. Sun, Y.F.; Li, J.H.; Cui, L.; Hua, B.; Cui, S.H.; Li, J.H.; Luo, J.L. A-site-deficiency facilitated in situ growth of bimetallic Ni-Fe nano-alloys: A novel coking-tolerant fuel cell anode catalyst. Nanoscale 2015, 7, 11173-11181. [CrossRef] [PubMed]

34. Spring, J.; Sediva, E.; Hood, Z.D.; Gonzalez-Rosillo, J.C.; O’Leary, W.; Kim, K.J.; Carrillo, A.J.; Rupp, J.L.M. Toward Controlling Filament Size and Location for Resistive Switches via Nanoparticle Exsolution at Oxide Interfaces. Small 2020, 16, 2003224. [CrossRef] [PubMed]

35. Gao, Y.; Chen, D.; Saccoccio, M.; Lu, Z.; Ciucci, F. From Material Design to Mechanism study: Nanoscale Ni Exsolution on a Highly Active A-site Deficient Anode Material for Solid Oxide Fuel Cells. Nano Energy 2016, 27, 499-508. [CrossRef]

36. Tang, C.; Kousi, K.; Neagu, D.; Portolés, J.; Papaioannou, E.I.; Metcalfe, I.S. Towards efficient use of noble metals via exsolution exemplified for CO oxidation. Nanoscale 2019, 11, 16935-16944. [CrossRef]

37. Momma, K.; Izumi, F. VESTA 3 for three-dimensional visualization of crystal, volumetric and morphology data. J. Appl. Crystallogr. 2011, 44, 1272-1276. [CrossRef]

38. Vecino-Mantilla, S.; Gauthier-Maradei, P.; Huvé, M.; Serra, J.M.; Roussel, P.; Gauthier, G.H. Nickel Exsolution-Driven Phase Transformation from an $\mathrm{n}=2$ to an $\mathrm{n}=1$ Ruddlesden-Popper Manganite for Methane Steam Reforming Reaction in SOFC Conditions. Chem CatChem 2019, 11, 4631-4641. [CrossRef]

39. Gálvez, M.E.; Jacot, R.; Scheffe, J.; Cooper, T.; Patzke, G.; Steinfeld, A. Physico-chemical changes in Ca, Sr and Al-doped La-Mn-O perovskites upon thermochemical splitting of $\mathrm{CO}_{2}$ via redox cycling. Phys. Chem. Chem. Phys. 2015, 17, 6629-6634. [CrossRef]

40. Ezbiri, M.; Takacs, M.; Stolz, B.; Lungthok, J.; Steinfeld, A.; Michalsky, R. Design principles of perovskites for solar-driven thermochemical splitting of $\mathrm{CO}_{2}$. J. Mater. Chem. A 2017, 5, 15105-15115. [CrossRef]

41. Donat, F.; Müller, C.R. $\mathrm{CO}_{2}$-free conversion of $\mathrm{CH}_{4}$ to syngas using chemical looping. Appl. Catal. B Environ. 2020, $278,119328$. [CrossRef]

42. Schneider, C.A.; Rasband, W.S.; Eliceiri, K.W. NIH Image to ImageJ: 25 years of image analysis. Nat. Methods 2012, 9, 671-675. [CrossRef] [PubMed] 